\title{
Effect of Phylloicus on leaf breakdown in a subtropical stream
}

\author{
Gabriela Tonello ${ }^{1, *}$, Letícia A. Naziloski ${ }^{1}$, Alan M. Tonin ${ }^{2,3}$, Rozane M. Restello ${ }^{1}$ and Luiz U. \\ Hepp $^{1}$
}

${ }^{1}$ Laboratório de Biomonitoramento. Departamento de Ciências Biológicas. Universidade Regional Integrada do Alto Uruguai e das Missões - Campus de Erechim. Avenida Sete de Setembro, 1621, Erechim, Rio Grande do Sul, Brasil. CEP: 99709-910.

${ }^{2}$ Laboratório de Limnologia. Departamento de Ecologia. Instituto de Ciências Biológicas. Universidade de Brasília. Asa Norte, Brasília, Distrito Federal, Brasil. CEP: 70910-900.

${ }^{3}$ Laboratorio de Ecología de Ríos, Faculdad de Ciencia y Tecnología, Universidad del País Vasco (UPV/EHU), 48940 Leioa, Spain.

*Corresponding author: gabi_tonello15@hotmail.com

Received: 10/02/2015

Accepted: 29/01/2016

\begin{abstract}
Effect of Phylloicus on leaf breakdown in a subtropical stream

Shredder invertebrates are key organisms in the decomposition of leaves in streams. These organisms transform coarse organic matter into fine organic matter, incorporate carbon and nutrients into animal biomass and promote the recycling of terrestrial carbon. Despite their importance in headwater streams, the life history of this shredder taxa and their relationship with organic matter processing is unclear. The main objectives of this study were to evaluate leaf breakdown during two periods of the year and test whether differences in the Phylloicus larvae abundance alter organic matter processing. We incubated leaves of a common native species (Campomanesia xanthocarpa) in the same stream during March (autumn) and October (spring). Samples were collected after 7, 15 and 30 days. After 30 days of incubation, the remaining leaf mass was lower in autumn (30\%) than in spring (53\%). The breakdown rate $(k)$ was $-0.0449 \pm 0.0042$ day $^{-1}$ in autumn and $-0.0180 \pm 0.0003$ day $^{-1}$ in spring. The abundance of Phylloicus was also higher in autumn than in spring (11.1 $\pm 1.9 \mathrm{ind} /$ litter bag versus $2.7 \pm 1.9 \mathrm{ind} /$ litter bag). We observed a positive correlation between Phylloicus abundance and leaf mass loss in autumn $(r=0.74)$. Our results demonstrate that Phylloicus abundance differs with season and impacts the processing of particulate organic matter. Furthermore, this work highlights the importance of Phylloicus larvae and their contribution to leaf breakdown in subtropical streams.
\end{abstract}

Key words: Shredders, aquatic macroinvertebrates, leaf litter decomposition, allocthonous organic matter.

\section{RESUMO}

\section{Efeito de Phylloicus sobre a decomposição foliar em um riacho subtropical}

Invertebrados fragmentadores são organismos chave para a decomposição de detritos foliares em riachos. Estes organismos transformam a matéria orgânica particulada grossa em matéria orgânica particulada fina e incorporam carbono e nutrientes em biomassa animal. Apesar de sua importância em riachos de cabeceira, a história de vida desse táxon fragmentador e sua relação com o processamento de matéria orgânica é incerta. O principal objetivo deste estudo foi avaliar a decomposição de detritos foliares em dois períodos do ano, a fim de testar se diferenças na abundância de larvas Phylloicus alteram o processamento dos detritos. Folhas senescentes de uma espécie nativa (Campomanesia xanthocarpa) foram incubadas em um riacho nos meses de Março (outono) e Outubro (primavera). Após 7, 15 e 30 dias de experimento foram coletadas amostras para análise. Ao término do experimento (após 30 dias), a massa remanescente das folhas foi menor no outono (30\%) do que na primavera (53\%). O coeficiente de decomposição foi de $\mathrm{k}=-0.0449 \pm 0.0042 \mathrm{dia}^{-1}$ no outono e de $\mathrm{k}=-0.0180 \pm 0.0003$ dia $^{-1}$ na primavera. A abundância de Phylloicus foi maior no outono quando comparada à primavera (11.1 \pm 1.9 ind/litter bag e $2.7 \pm 1.9$ ind/litter bag, respectivamente). Observamos uma correlação positiva entre a abundância de Phylloicus e a perda de massa dos detritos foliares no outono $(\mathrm{r}=0.74)$. A abundância de Phylloicus variou entre as duas estações estudadas, $o$ que esteve relacionado com o processamento dos detritos foliares. Nossos resultados também indicaram a importância das larvas de Phylloicus e sua contribuição para a decomposição foliar em riachos subtropicais.

Palavras-chave: Fragmentadores, macroinvertebrados aquáticos, decomposição foliar, matéria orgânica alóctone. 


\section{INTRODUCTION}

Leaf litter decomposition is one of the main flow routes of energy and nutrients into forested headwater streams and is mediated by both microorganisms and shredder invertebrates (Dobson et al., 2002). Shredders transform organic matter from coarse to fine, dissolve particles and carbon, and incorporate carbon and other nutrients into animal biomass (Allan \& Castillo, 2007). Thus, they play an important role in transforming organic matter into small particles and releasing nutrients that are then used by other organisms (Graça, 2001; Jabiol et al., 2013). Based on their contribution, studies in subtropical (Tonin et al., 2014a), tropical (Gonçalves et al., 2007; Camacho et al., 2009) and temperate regions (Johnsson et al., 2001; Huryn et al., 2002) have indicated that the breakdown rate of organic matter is positively related to the abundance and/or biomass of shredders; these results were also observed under laboratory conditions (Ferreira et al., 2006; Navarro et al., 2013). Furthermore, it is estimated that shredders contribute from 51 to $64 \%$ of the total leaf mass loss in temperate climates (fungi and bacteria also contribute 15 to $18 \%$ and 7 to $9 \%$, respectively) (Hieber \& Gessner, 2002).

The Calamoceratidae family (Trichoptera) contains typical shredders that are found in Neotropical regions (Pattersen \& Vannote, 1979). Larvae of the genus Phylloicus Müller 1880, which are exclusively shredders, are usually found in pool-like areas, where leaves accumulate in headwater streams (Wantzen \& Wagner, 2006). The Phylloicus genus includes 60 endemic species of the Neotropical region, and some species extend into the southwestern United States (Holzenthal et al., 2007).

Several authors have reported that shredders are underrepresented in tropical streams, where Phylloicus larvae are present, compared to temperate streams (Wantzen et al., 2008; Jacobsen et al., 2008; Li \& Dudgeon, 2008; Boyero et al., 2011; Gonçalves et al., 2012; König et al., 2014). Some hypotheses have been proposed to explain the low abundance of shredders and the uncertainty of their role in leaf breakdown in tropi- cal streams. One hypothesis is that many invertebrate shredders (mainly insects of Plecoptera and Trichoptera) evolved in colder water and are less prevalent in lower latitudes (Boyero et al., 2012). Thus, it is suggested that the decomposition in tropical systems is mainly driven by microorganisms (i.e., aquatic fungi and bacteria), which are stimulated by higher water temperatures (Irons et al., 1994). It has also been suggested that the low occurrence of shredders in tropical systems could be an artefact of the increased local variation in these taxa or a result of the temporal variations (Camacho et al., 2009). The low relative abundance of shredders could also be due to their large body size compared with many other invertebrates; this would mask their contribution to leaf processing (Tonin et al., 2014a).

Our aim was to evaluate leaf breakdown at two periods of the year and test whether differences in shredder abundance altered the leaf breakdown rates. Our hypothesis was that the abundance of Phylloicus would differ between the two periods of the year due to fluctuations in the environmental factors that influence biological communities. Thus, we further hypothesised that there would be an increase in the leaf breakdown rates during the period of greatest abundance of Phylloicus due to increased feeding activity.

\section{MATERIAL AND METHODS}

\section{Study area}

The study was conducted in a first-order stream $\left(27^{\circ} 43^{\prime} 07^{\prime \prime} \mathrm{S} ; 52^{\circ} 18^{\prime} 20^{\prime \prime} \mathrm{W}\right)$ in a subtropical climate (southern Brazil). The annual average temperature at the site is $17 \pm 1{ }^{\circ} \mathrm{C}$, and the annual rainfall ranges from 1.900 to $2.200 \mathrm{~mm}$ (Alvares et al., 2013). The site is within the Araucaria Rain Forest, which is part of the Atlantic Forest domain (Oliveira-Filho et al., 2015). The riparian vegetation species include Araucaria angustifolia (Araucariaceae), Vernonia discolor (Asteraceae), Piptocarpha angustifolia (Asteraceae), Apuleia leiocarpa, Myrocarpus frondo- 
sus, Albizia edwalli (Fabaceae), Campomanesia xanthocarpa (Myrtaceae) and Sebastiania brasiliensis (Euphorbiaceae).

\section{Leaves and field experiment}

We selected a plant species common to both the Araucaria Rain Forest and the riparian zone of subtropical streams (Campomanesia xanthocarpa O. Berg, Myrtaceae; Oliveira-Filho et al., 2015). Senescent leaves were collected from a single forest fragment $\left(27^{\circ} 38^{\prime} 59^{\prime \prime} \mathrm{S}\right.$ and $52^{\circ}$ $16^{\prime} 12^{\prime \prime} \mathrm{W}$ ) in autumn 2010 using suspended nets. The leaves were air dried, homogenised and weighed. C. xanthocarpa leaves have $2.1 \pm 0.1 \%$ nitrogen, $0.040 \pm 0.005 \%$ phosphorus and $4.0 \pm 0.2 \%$ tannins (for more details, see Tonin et al., 2014b).

The experiment was conducted in two periods: autumn (March 2011) and spring (October 2011). We performed the experiment at periods when we expected differences in leaf input to the streams based on previous observations (unpublished results). Tropical plant species have asynchronous loss of their leaves, and leaves can fall year-round (Mathooko et al., 2000). However, previous observations in subtropical regions have shown that falling leaves are more pronounced in the autumn due to the intrinsic characteristics of plant species. In each period, we incubated 12 litter bags $(15 \times 20 \mathrm{~cm} ; 10 \mathrm{~mm}$ mesh size $)$ containing $3.0 \pm 0.1 \mathrm{~g}$ of leaf litter. We use a correction factor to consider differences between the air and oven dry mass $\left(35^{\circ} \mathrm{C}, 48 \mathrm{~h}\right)$ of leaves. The same pool of leaves was used for the experiments in both periods (i.e., autumn and spring). Four litter bags were randomly retrieved after 7,15 and 30 days of incubation in the stream to assess the leaf mass loss and the colonisation of invertebrates.
During each experimental period, the water temperature, $\mathrm{pH}$, turbidity, electrical conductivity and dissolved oxygen were measured using a Horiba $® U-50$ multi-analyser.

\section{Laboratory procedures}

After removing the litter bags, the leaves were washed through a $250 \mu \mathrm{m}$ sieve to remove sediments and collect invertebrates. The remaining leaves were dried $\left(35^{\circ} \mathrm{C}, 48 \mathrm{~h}\right)$ and weighed to determine the remaining dry mass. Invertebrates were identified to the family level and counted. Individuals of the genus Phylloicus (Calomoceratidae, Trichoptera) were separated from nonshredder taxa. We found one Tipuliidae larvae (autumn) and one Gripopterygidae larvae (spring); these insects are also shredders. However, for the purposes of our analyses, we counted only the Phylloicus genus as shredders due to the low representativeness of the other two taxa. The identification of organisms was performed using the taxonomic keys of Fernandez and Domingues (2001), Mugnai et al. (2010) and Pes et al. (2005) using a stereomicroscope at $30 \times$ magnification.

\section{Data analysis}

Each limnological variable was tested for significance between the experimental periods using a $t$-test. The decomposition rates $\left(-k \mathrm{day}^{-1}\right)$ were calculated according to a negative linear model ( $W_{t}=-k * t+W_{0}$ ), where the remaining mass $W_{t}$ (ln-transformed) is the weight at time $t$ (days), $W_{0}$ is the initial mass and $-k$ is the decomposition coefficient (Webster \& Benfield, 1986). We used an analysis of covariance (ANCOVA) test with time as a covariate to evaluate differences in the

Table 1. Limnological variables (mean \pm SE) during experimental periods (autumn and spring of 2011). Variáveis limnológicas (média \pm EP) durante os períodos experimentais (outono e primavera de 2011).

\begin{tabular}{lcccc}
\hline Variables & Autumn & Spring & $t$ & $P$ \\
\hline Water temperature $\left({ }^{\circ} \mathrm{C}\right)$ & $17.9 \pm 1.5$ & $17.4 \pm 1.2$ & -0.46 & 0.65 \\
$\mathrm{pH}$ & $7.0 \pm 0.4$ & $6.6 \pm 0.3$ & 0.21 & 0.84 \\
Turbidity $(\mathrm{NTU})$ & $5.1 \pm 1.2$ & $4.3 \pm 1.0$ & -1.74 & 0.12 \\
Conductivity $(\mu \mathrm{S} / \mathrm{cm})$ & $20.0 \pm 0.0$ & $20.0 \pm 0.0$ & -0.73 & 0.48 \\
Dissolved oxygen $(\mathrm{mg} / \mathrm{L})$ & $12.0 \pm 3.0$ & $13.0 \pm 1.0$ & 0.41 & 0.69 \\
\hline
\end{tabular}




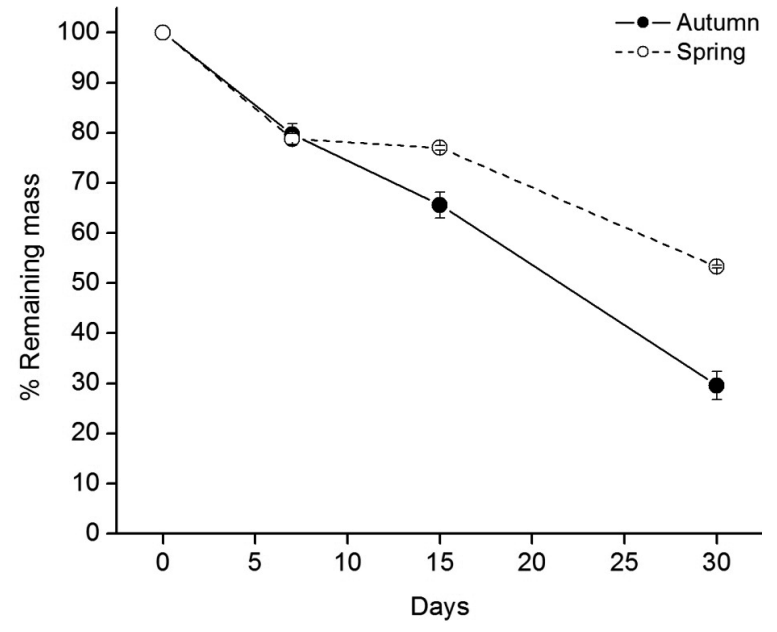

Figure 1. Remaining mass ( $\%$; mean $\pm \mathrm{SE})$ of Campomanesia xanthocarpa leaves during experimental periods (i.e., autumn and spring of 2011) in a subtropical stream. Diferenças na porcentagem de massa remanescente (média $\pm E P$ ) de Campomanesia xanthocarpa durante os períodos experimentais (outono e primavera de 2011) em um riacho subtropical.

remaining mass of leaf litter between the experimental periods (i.e., autumn and spring). We used Student's $t$-tests to evaluate differences in the final total abundance of Phylloicus and all other invertebrates (grouped) between the experimental periods. Pearson correlations were used to test whether the abundance of Phylloicus and other invertebrates (excluding Phylloicus) was correlated with leaf mass loss in autumn and spring. All analyses were performed using the "vegan" package (Oksanen et al., 2011) in the R software (R Core Team, 2013).

\section{RESULTS}

The limnological variables were similar for both experimental periods (Table 1). During the two periods, water was well oxygenated $(>12 \mathrm{mg} / \mathrm{L})$, had low electrical conductivity $(\sim 20 \mu \mathrm{s} / \mathrm{cm})$, was slightly acid $(\sim 6.7)$ and had a mean temperature of $17-18{ }^{\circ} \mathrm{C}$ (Table 1$)$.

After 30 days, the leaf remaining mass was lower in autumn $(30 \%)$ than in spring $(53 \%)$ (ANCOVA, $F_{(1,29)}=12.9 ; p=0.001 ;$ Fig. 1$)$. The breakdown rate $(k)$ was $-0.0449 \pm 0.0042$ day $^{-1}$ in autumn and $-0.0180 \pm 0.0003$ day $^{-1}$ in spring.

Phylloicus abundance was higher in autumn (11.1 $\pm 1.9 \mathrm{ind} /$ litter bag, $8 \%$ of total organisms) than in spring $(2.6 \pm 1.9$ ind/litter bag; $2 \%$ of total organisms; $t=3.04 ; \mathrm{df}=22 ; p=0.005$; Fig. 2A). We also observed a positive association between other invertebrates and leaf mass loss during both periods (spring: $r=0.71, p=0.008$
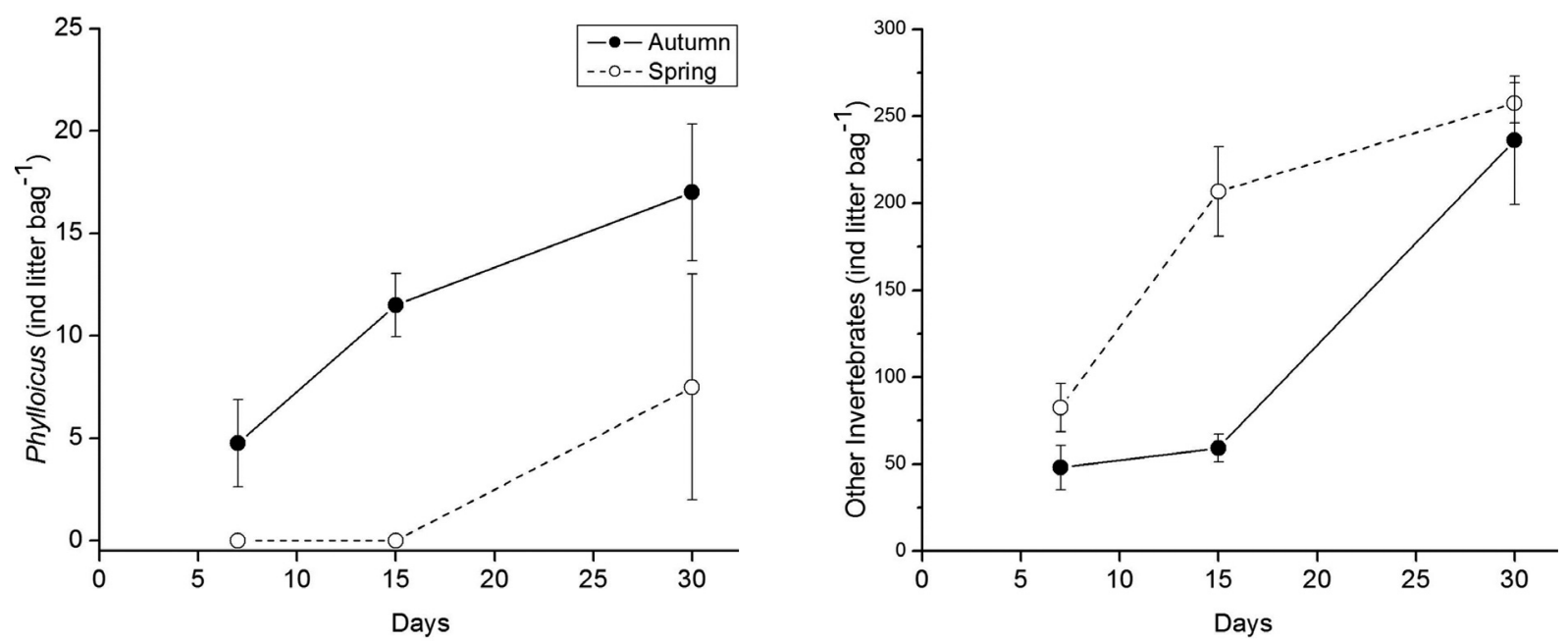

Figure 2. Mean \pm SE abundance (organisms per litter bag) of (A) Phylloicus and (B) other invertebrates during the experimental periods (autumn and spring of 2011) in a subtropical stream. Média \pm EP da abundância (organismos por litter bag) de (A) Phylloicus $e(B)$ outros invertebrados, durante os períodos experimentais (outono e primavera de 2011) em um riacho subtropical. 
and autumn: $r=0.88, p<0.001)$. However, when the non-shredder taxa Chironomidae $(45 \%$ of total invertebrate abundance; $r=0.41, p=0.17$ ) was removed, this relationship was no longer present. In the autumn, the relationship with other invertebrates (without non-shredder Chironomidae taxa) was significant $(r=0.68$, $p=0.01)$.

The abundance of other invertebrates was higher in spring $(179.6 \pm 23.2 \mathrm{ind} /$ litter bag, $92 \%$ of total organisms) than in autumn $(103.4 \pm 27.4$ ind/litter bag; $98 \%$ of total organisms; $t=-2.38$; df $=22 ; p=0.026$; Fig. 2B). Chironomidae and Simuliidae were the most abundant families during both experimental periods. These organisms accounted for $49.7 \%$ and $16 \%$, respectively, of the total fauna in autumn and $79.9 \%$ and $9.9 \%$, respectively, in spring (Table 2).

\section{DISCUSSION}

We observed that the abundance of Phylloicus was an important predictor of leaf litter process-

Table 2. Abundance (mean \pm SE) of other invertebrates (excluding Phylloicus) during experimental periods (autumn and spring of 2011). Abundância (média \pm EP) dos outros invertebrados (excluindo Phylloicus), durante os períodos experimentais (outono e primavera de 2011).

\begin{tabular}{|c|c|c|c|c|c|c|}
\hline \multirow{2}{*}{ Taxa } & \multicolumn{3}{|c|}{ Autumn } & \multicolumn{3}{|c|}{ Spring } \\
\hline & Day 7 & Day 15 & Day 30 & Day 7 & Day 15 & Day 30 \\
\hline Acarina & - & - & $0.2 \pm 0.2$ & - & - & - \\
\hline Bivalvia & - & - & $0.2 \pm 0.2$ & - & - & - \\
\hline \multicolumn{7}{|l|}{ Diptera } \\
\hline Ceratopogonidae & - & - & $0.7 \pm 0.7$ & & & \\
\hline Chironomidae & $9 \pm 3.4$ & $21.2 \pm 2.7$ & $124 \pm 18.9$ & $60.2 \pm 11.6$ & $168.2 \pm 19.8$ & $205.5 \pm 12$ \\
\hline Dixidae & - & - & $1.5 \pm 0.6$ & $0.2 \pm 0.2$ & - & $0.5 \pm 0.2$ \\
\hline Empididae & - & $0.5 \pm 0.2$ & & - & - & \\
\hline Simuliidae & $17.7 \pm 7.8$ & $1.2 \pm 0.4$ & $33.2 \pm 28.9$ & $6 \pm 3.5$ & $20.2 \pm 3.9$ & $28 \pm 13.7$ \\
\hline Tipulidae & $0.2 \pm 0.2$ & - & - & - & - & - \\
\hline Coleoptera & & - & & & & \\
\hline Dytiscidae & - & - & - & $0.5 \pm 0.5$ & $0.7 \pm 0.7$ & $0.2 \pm 0.2$ \\
\hline Elmidae & $6.5 \pm 1.3$ & $7.7 \pm 2.7$ & $14 \pm 4.6$ & $1 \pm 0.5$ & $2 \pm 1.1$ & $5.2 \pm 2.3$ \\
\hline Hydrophilidae & - & - & - & $0.5 \pm 0.5$ & - & $0.2 \pm 0.2$ \\
\hline Hyrudinea & - & - & - & $2.7 \pm 1.7$ & $3.7 \pm 1.4$ & - \\
\hline Ephemeroptera & & - & & & & \\
\hline Baetidae & - & - & $1.7 \pm 0.2$ & $0.2 \pm 0.2$ & $0.7 \pm 0.7$ & $0.5 \pm 0.2$ \\
\hline Leptophlebiidae & - & $0.2 \pm 0.2$ & $0.2 \pm 0.2$ & - & - & $0.5 \pm 0.5$ \\
\hline Megaloptera & - & $0.7 \pm 0.2$ & - & - & - & - \\
\hline Oligochaeta & $1.2 \pm 0.4$ & $12.5 \pm 5.3$ & $2 \pm 0.9$ & $10.5 \pm 2.5$ & $8.5 \pm 3.3$ & $7.7 \pm 5.4$ \\
\hline Plecoptera & & - & & & & \\
\hline Perlidae & $0.2 \pm 0.2$ & - & - & - & $0.2 \pm 0.2$ & - \\
\hline Gripopterigydae & - & - & - & - & - & $0.2 \pm 0.2$ \\
\hline Odonata & & - & & & & \\
\hline Calopterigidae & $0.2 \pm 0.2$ & $0.5 \pm 0.5$ & $2 \pm 1.2$ & - & - & - \\
\hline \multicolumn{7}{|l|}{ Trichoptera } \\
\hline Hydropsichidae & $8 \pm 3.4$ & $3.0 \pm 0.9$ & $38.5 \pm 9.3$ & - & $0.7 \pm 0.4$ & $1.2 \pm 0.9$ \\
\hline Hydroptilidae & - & - & - & - & $1 \pm 1$ & $0.2 \pm 0.2$ \\
\hline Polycentropodidae & - & - & - & $1 \pm 0.4$ & $1.7 \pm 0.7$ & $0.5 \pm 0.2$ \\
\hline Hydrobiosidade & - & - & $0.7 \pm 0.4$ & - & - & - \\
\hline
\end{tabular}


ing in the studied stream. The higher abundance of Phylloicus in autumn increased leaf breakdown 4-fold compared with the spring period. Similar results were observed by Ferreira et al. (2006), who showed an increase in leaf mass loss in the presence of shredders under laboratory conditions. Although it is expected that shredders accelerate leaf litter processing due to their higher than average consumption rates (Graça, 2001), few experimental studies have tested whether shredders are important to leaf processing in subtropical streams (König et al., 2014; Tonin et al., 2014a). In the field, Gonçalves et al. (2007) observed that a high density of shredders was responsible for the high mass loss of Protium brasiliense leaves in a tropical stream. Thus, the activity of typical shredders is important because it promotes the fragmentation of leaves and contributes to the flow of matter and energy from headwaters to downstream areas (Graça, 2001). Additionally, the breakdown rate of $C$. xanthocarpa in autumn and spring can be considered fast $\left(k>0.0173 \mathrm{~d}^{-1}\right)$, according to the classification system proposed by Gonçalves et al. (2013). These values were higher than those reported in studies conducted in subtropical regions, where the abundance of shredders was less than $1 \%$ (Trevisan \& Hepp, 2007; Hepp et al., 2008; Tonello et al., 2014).

Differences in Phylloicus abundance between autumn and spring can be attributed to life cycle and patterns of litter input to the stream. Norwood \& Stewart (2002) observed that a Neotropical species of Phylloicus (Phylloicus ornatus) had oviposition between spring and summer and that its larval final stages coincided with autumn; this coincides with the greater abundance of Phylloicus larvae observed in this study. In addition, the higher Phylloicus abundance in autumn can be explained by a higher litter input to the streams and, thus, greater resource availability. However, litter input into subtropical streams in the Atlantic Forest Biome tends to be constant throughout the year, with few discrete peaks in certain months (Afonso et al., 2000; Lisboa et al., 2015). Thus, there is a higher probability of an increase in Phylloicus abundance due to favourable conditions rather than resource availability; this was not addressed in the present study.

The low abundance $(<10 \%)$ of the typical shredders reported for tropical and subtropical streams (Boyero et al., 2012; Tonello et al., 2014; Tonin et al., 2014a) is consistent with our study's observations. Despite this general pattern, we observed a higher variability of Phylloicus abundance between the seasons (11 individuals per bag in autumn vs. $<3$ in spring), which demonstrates the importance of understanding the shredder abundance patterns over a year and the life cycles of key shredder species in clarifying their role in stream litter processing.

Other non-shredder invertebrates had opposite patterns from Phylloicus (i.e., higher abundance in spring), but these patterns were not consistent after removing Chironomidae from the analyses. This suggests that the abundance of other invertebrates was not correlated with leaf mass loss. Additionally, an increase in invertebrate abundance over time is expected due to the colonisation of leaf litter as a substrate and/or the release of fine organic particles, which generally increase with incubation time (Ligeiro et al., 2010; Biasi et al., 2013). Chironomidae was the most abundant taxon during both periods, with 3fold higher abundance in spring than in autumn. These are the dominant organisms in streams that contain numerous substrate types, including leaf litter (Hepp et al., 2008; Ligeiro et al., 2010; Biasi et al., 2013). However, chironomids are not typical shredders (Canhoto \& Graça, 1999), and their high abundance does not specifically indicate the processing of coarse particulate organic matter.

Our results highlight the relative importance of typical shredders as consumers of leaf litter in subtropical streams, even if they represent less than $10 \%$ of the total invertebrates. The feeding activity and metabolic rates of this functional group intensify litter processing, which represents an essential ecological process in stream ecosystems. Finally, we show patterns of occurrence and biological fragmentation in less-studied subtropical streams. 


\section{ACKNOWLEDGMENTS}

RMR received financial support from CNPQ (proc.\#477274/2011-0 and proc.\#475251/2009-1). GT received scholarship from FAPERGS/Brazil. LUH received financial support from $\mathrm{CNPq}$ (proc.\#471572/2012-8). AMT received scholarship from PIIC/URI/Brazil.

\section{REFERENCES}

AFONSO, A. A. O., R. HENRY \& R. C. S. M. RODELLA. 2000. Allochthonous matter input in two different stretches of a headstream (Itatinga, São Paulo, Brazil). Brazilian Archives of Biology and Technology, 43: 335-343.

ALLAN, D. J. \& M. M. CASTILLO. 2007. Stream ecology: structure and function of running waters. Springer. Berlin Heidelberg, Germany.

ALVARES, C. A., J. L. STAPE, P. C. SENTELHAS, J. L. M. GONÇALVES \& G. SPAROVEK. 2013. Köppen's climate classification map for Brazil. Meteorologische Zeitschrift, 22: 711-728.

BIASI, C., A. M. TONIN, R. M. RESTELLO \& L. U. HEPP. 2013. The colonisation of leaf litter by Chironomidae (Diptera): The influence of chemical quality and exposure duration in a subtropical stream. Limnologica, 43: 427-433.

BOYERO, L., R. G. PEARSON, D. DUDGEON, M. A. S GRAÇA, M. O. GESSNER, R. J. ALBARINO, V. FERREIRA, C. M. YULE, A. J. BOULTON, A. MUTHUKUMARASAMY, M. CALLISTO, E. CHAUVET, A. RAMÍREZ, J. CHARÁ, M. S. MORETTI, J. F. GONÇALVES, J. E. HELSON, A. M. CHARÁ-SERNA, A. ENCALADA, J. N. DAVIES, S. LAMOTHE, A. CORNEJO, A. O. Y. LI, L. M. BURIA, V. D. VILLANUEVA, M. D. ZÚNIGA \& C. M. PRINGLE. 2011. Global distribution of a key trophic guild contrasts with common latitudinal diversity patterns. Ecology, 92: 1839-1848.

BOYERO, L., R. G. PEARSON, D. DUDGEON, V. FERREIRA, M. A. S. GRAÇA, M. O. GESSNER, A. J. BOULTON, E. CHAUVET, C. M. YULE, R. J. ALBARIÑO, A. RAMÍREZ, J. E. HELSON, M. CALLISTO, M. ARUNACHALAN, J. CHARÁ, R. FIGEROA, J. M. MATHOOKO, J. F. GONÇALVES, M. S. MORETTI, A. M. CHARÁSERNA, J. N. DAVIES, A. ENCALADA, S. LA-
MOTHE, L. M. BURIA, J. CASTELA, A. CORNEJO, A. O. Y. LI, C. M'ERIMBA, V. D. VILLANUEVA, M. D. ZÚNIGA, C. M. SWAN \& L. A. BARMUTA. 2012. Global patterns of stream detritivore distribution: implications for biodiversity loss in changing climates. Global Ecology and Biogeography, 21: 134-141.

CAMACHO, R., L. BOYERO, A. CORNEJO, A. IBÁÑEZ \& L. G. PEARSON. 2009. Local variation in shredder distribution can explain their oversight in tropical streams. Biotropica, 41: 625-632.

CANHOTO, C. \& M. A. S. GRAÇA. 1999. Leaf barriers to fungal colonization and shredders (Tipula lateralis) consumption of decomposing Eucalyptus globulus. Microbial Ecology, 37: 163-172.

DOBSON, M., A. MAGANA, J. M. MATHOOKO \& F. K. NDEGWA. 2002. Detritivores in Kenyan highland streams: more evidence for the paucity of shredders in the tropics? Freshwater Biology, 47: 909-919.

FERREIRA, V., M. A. S. GRAÇA, J. L. M. P. LIMA \& R. GOMES. 2006. Role of physical fragmentation and invertebrate activity in the breakdown rate of leaves. Archive für Hydrobiology, 165: 493513.

FERNANDEZ, H. R. \& E. DOMINGUES. 2001. Guía para la determinación de los artrópodos bentônicos sudamericanos. UNT. Tucumán, Argentina.

GONÇALVES, J. F., M. A. S. GRAÇA \& M. CALLISTO. 2007. Litter decomposition in a Cerrado savannah stream is retarded by leaf toughness, low dissolved nutrients and a low density of shredders. Freshwater Biology, 52: 1440-1451.

GONÇALVES, J. F., R. S. REZENDE, N. M. MARTINS \& R. S. GREGÓRIO. 2012. Leaf breakdown in an Atlantic Rain-Forest stream. Austral Ecology, 37: 807-815.

GONÇALVES, J. F., R. T. MARTINS, B. M. P. OTTONI \& S. R. M. COUCEIRO. 2013. Visão sobre a decomposição foliar em sistemas aquáticos brasileiros. In: Insetos Aquáticos na Amazônia Brasileira: taxonomia, biologia e ecologia. N. Hamada, J. L. Nessimian \& R. B. Querino (Eds.): 89116. Editora do INPA, Manaus, Brasil.

GRAÇA, M. A. S. 2001. The role of invertebrates on leaf decomposition in streams: a review. International Review of Hydrobiology, 86: 383-393.

HEPP, L. U., C. BIASI, S. V. MILESI, F. O. VEIGA \& R. M. RESTELLO. 2008. Chironomidae (Diptera) 
larvae associated to Eucalyptus globulus and $E u$ genia uniflora leaf litter in a subtropical stream (Rio Grande do Sul, Brazil). Acta Limnologica Brasiliensia, 20: 345-350.

HIEBER, M. \& M. O. GESSNER. 2002. Contribution of stream detritivores, fungi, e bacteria to leaf breakdown based on biomass estimates. Ecology, 83:1026-1038.

HOLZENTHAL, R. W., R. J. BLAHNIK, A. L. PRATHER \& K. M. KJER. 2007. Order Trichoptera Kirby, 1813 (Insecta), Caddisflies. Zootaxa, 1668: 639-698.

HURYN, A. D., V. M. B. HURYN, C. J. ARBUCKLE $\&$ L. TSOMIDES. 2002. Catchment land-use, macroinvertebrates and detritus processing in headwater streams: taxonomic richness versus function. Freshwater Biology, 47: 401-415.

IRONS, J. G., M. W. OSWOOD, R. J. STOUT \& C. M. PRINGLE. 1994. Latitudinal patterns in leaf litter breakdown: is temperature really important? Freshwater Biology, 32: 401-411.

JABIOL, J., B. G. McKIE, A. BRUDER, C. BERNADET, M. O. GESSNER \& E. CHAUVET. 2013. Trophic complexity enhances ecosystem functioning in an aquatic detritus-based model system. Journal of Animal Ecology, 82: 1042-1051.

JACOBSEN, D., C. CRESSA, J. M. MATHOOKO \& D. DUDGEON. 2008. Macroinvertebrates: composition, life histories and production. In: Tropical Stream Ecology. D. Dudgeon (ed.): 65-105. Academic Press, Elsevier. UK.

JOHNSSON, M., B. MALMQVIST \& P. O. HOFFSTEN. 2001: Leaf breakdown rates in boreal streams: does shredder species richness matter? Freshwater Biology, 46: 161-171.

KÖNIG, R., L. U. HEPP \& S. SANTOS. 2014. Colonisation of low- and high-quality detritus by benthic macroinvertebrates during leaf breakdown in a subtropical stream. Limnologica, 45: 61-68.

LI, A. O. Y. \& D. DUDGEON. 2008. Food resources of shredders and other benthic macroinvertebrates in relation to shading conditions in tropical Hong Kong streams. Freshwater Biology, 53: 2011-2025.

LIGEIRO, R., M. S. MORETTI, J. F. GONÇALVES \& M. CALLISTO. 2010. What is more important for invertebrate colonization in a stream with lowquality litter inputs: exposure time or leaf species? Hydrobiologia, 654: 125-136.

LISBOA, L. K., A. L. L. SILVA, A. E. SIEGLOCH, J. F. GONÇALVES \& M. M. PETRUCIO. 2015.
Temporal dynamics of allochthonous coarse particulate organic matter in a subtropical Atlantic rainforest Brazilian stream. Marine and Freshwater Research, 66: 674-680.

MATHOOKO, J. M., A. M. MAGANA \& I. M. NYANG'AU. 2000. Decomposition of Syzygiumcordatum leaves in a Rift valley stream ecosystem. African Journal of Ecology, 38: 365-368.

MUGNAI, R., J. L. NESSIMIAN \& D. F. BAPTISTA. 2010. Manual de identificação de macroinvertebrados aquáticos do estado do Rio de Janeiro. Technical Books Editora. Brasil.

NAVARRO, F. R. S. P., R. S. REZENDE \& J. F. GONÇALVES. 2013. Experimental assessment of temperature increase and presence of predator carcass changing the response of invertebrate shredders. Biota Neotropica, 13: 38-33.

NORWOOD, J. C. \& K. W. STEWART. 2002. Life history and case-building behavior of Phylloicus ornatus (Trichoptera: Calamoceratidae) in two spring-fed streams in Texas. Ecology and Population Biology, 95: 44-56.

OKSANEN, J., F. G. BLANCHET, R. KINDT, P. LEGENDRE, R. B. O'HARA, G. L. SIMPSON, P. SOLYMOS, M. H. STEVENS, H. WAGNER. 2011. Multivariate Analysis of Ecological Communities in R. http://vegan.r-forge.r-project.org/

OLIVEIRA-FILHO, A. T., J. C. BUDKE, J. A. JARENKOW, P. V. EISENLOHR \& D. R. M. NEVES. 2015. Delving into the variations in tree species composition and richness across South American subtropical Atlantic and Pampean forests. Journal of Plant Ecology, 8: 242-260.

PATTERSEN, J. W. \& R. L. VANNOTE. 1979. Life history and population dynamics of Heteroplectron americanum. Environmental Entomology. 8: 665669.

PES, M. A. O., N. HAMADA \& J. L. NESSIMIAN. 2005. Chaves de identificação de larvas para famílias e gêneros de Trichoptera (Insecta) da Amazônia Central, Brasil. Revista Brasileira de Entomologia, 49: 181-204.

R CORE TEAM. 2013. R: A language and environment for statistical computing. R Foundation for Statistical Computing. http://www.R-project.org.

TONELLO, G., R. C. LOUREIRO, P. KRAUSE, C. SILVA, R. M. ONGARATTO, S. SEPP, R. M. RESTELLO \& L. U. HEPP. 2014. Colonização de invertebrados durante a decomposição de diferentes detritos vegetais em um riacho subtropical. Revista Brasileira de Biociências, 12: 98-105. 
TONIN, A. M., L. U. HEPP, R. M. RESTELLO \& J. F. GONÇALVES. 2014a. Understanding of colonization and breakdown of leaves by invertebrates in a tropical stream is enhanced by using biomass as well as count data. Hydrobiologia, 740: 79-88.

TONIN, A. M., R. M. RESTELLO \& L. U. HEPP. 2014b. Chemical changes of leaves during breakdown affects associated invertebrates in a subtropical stream. Acta Limnologica Brasiliensia, 26: 235-244.

TREVISAN, A. \& L. U. HEPP. 2007. Dinâmica de componentes químicos vegetais e fauna associada ao processo de decomposição de espécies arbóreas em um riacho do norte do Rio Grande do Sul. Neotropical Biology and Conservation, 2: 54-60.

WANTZEN, K. M. \& R. WAGNER. 2006. Detritus processing by invertebrate shredders: a neotropical-temperate comparison. Journal of North American Benthological Society, 25: 216-232.

WANTZEN, K. M., C. M. YULE, J. M. MATHOOKO \& C. M. PRINGLE. 2008. Organic matter processing in tropical streams. In: Tropical Stream Ecology. D. Dudgeon (ed.): 43-64. Academic Press, Elsevier, UK.

WEBSTER, J. R. \& E. F. BENFIELD. 1986. Vascular plant breakdown in freshwater ecosystems. Annual Review of Ecology and Systematics, 17: 567-594. 
